\title{
Notes on the vocalizations of Rufous Paradise-flycatcher (Terpsiphone cinnamomea)
}

\section{Peter Boesman}

In the following we briefly analyze and compare voice of the three races of Rufous Paradiseflycatcher (Terpsiphone cinnamomea). We also try to quantify the extent of any vocal differences using the criteria proposed by Tobias et al. (2010), as a support for taxonomic review. We have made use of sound recordings available on-line from Xeno Canto (XC) and Macaulay Library (ML).

Song of the all races is structurally similar: a long series of a repeated single upslurred whistle. Pace apparently quite variable. Comparison of sonograms of the three races:

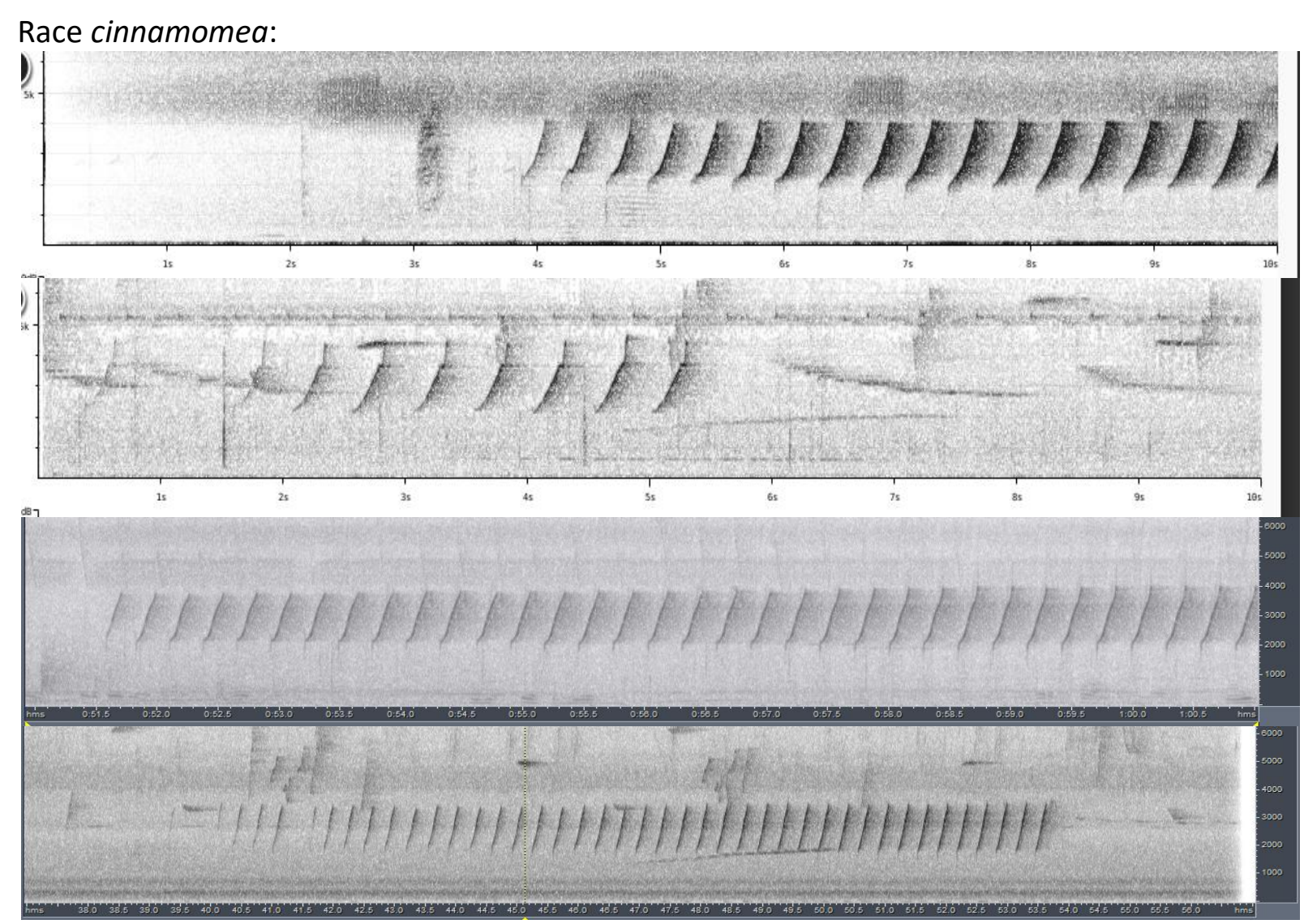

\section{Race unirufa}

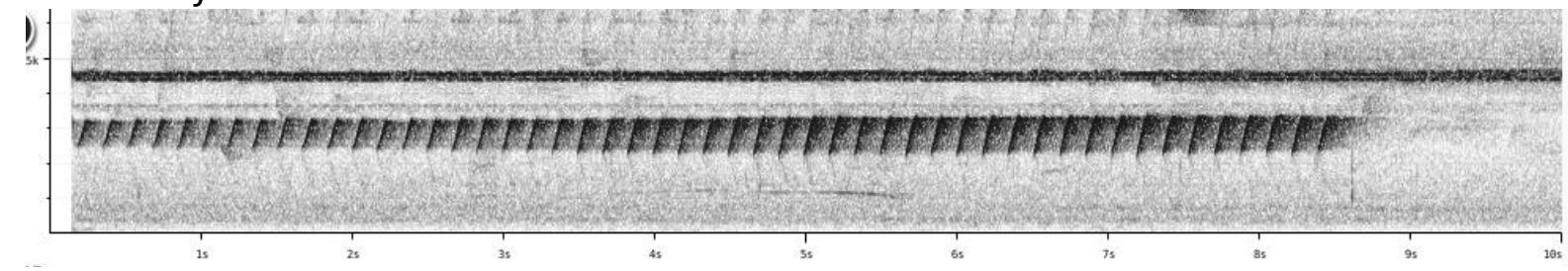



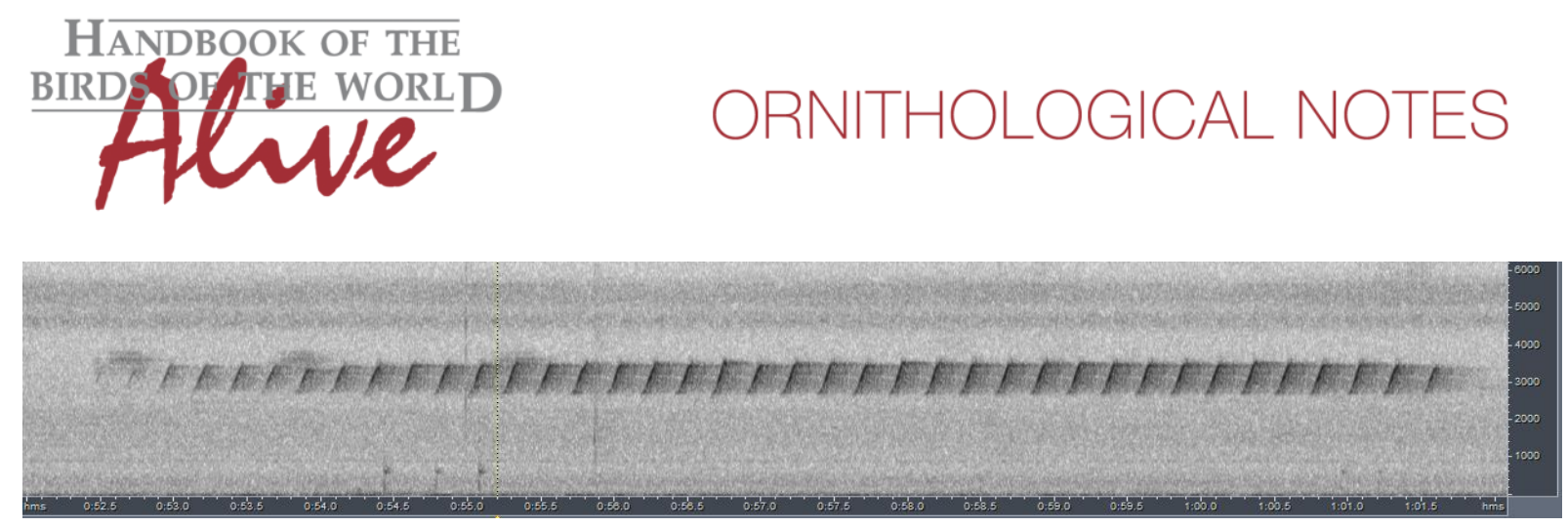

Race talautensis

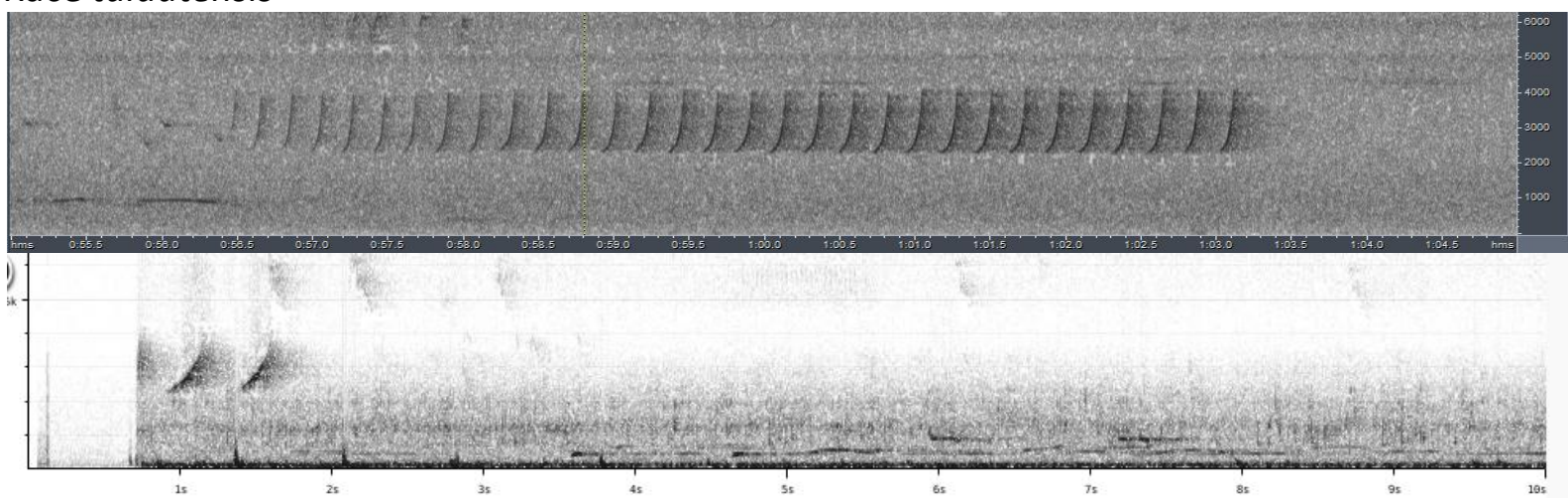

Difference in song is quite clear from the above examples (although sample size is very small for unirufa and talautensis):

cinnamomea and talautensis are very similar, unirufa at the other hand has apparently a much narrower frequency range (c. $0.9-1.1 \mathrm{kHz}$ vs c. $1.8-2.2 \mathrm{kHz}$, score 3), with slightly shorter note duration (score 1 ). When applying Tobias criteria, this would lead to a total vocal score of 4 .

There is one recording of cinnamomea (XC239338) where one bird sings a song in a narrow frequency range and is responded by a bird singing whistles in a broad frequency range. This is the only somewhat deviating recording we have found, and it is unclear what is the context of these two different vocalisations. Needs further investigation.

This note was finalized on 22nd January 2016, using sound recordings available on-line at that moment. We would like to thank in particular the sound recordists who placed their recordings for this species on XC and ML: Desmond Allen, David Edwards, Peter Hosner, Robert Kennedy, Ben King, Frank Lambert, Mike Nelson and Paul Noakes.

\section{References}

Tobias, J.A., Seddon, N., Spottiswoode, C.N., Pilgrim, J.D., Fishpool, L.D.C. \& Collar, N.J. (2010). Quantitative criteria for species delimitation. Ibis 152(4): 724-746.

\section{Recommended citation}

Boesman, P. (2016). Notes on the vocalizations of Rufous Paradise-flycatcher (Terpsiphone cinnamomea). HBW Alive Ornithological Note 198. In: Handbook of the Birds of the World Alive. Lynx Edicions, Barcelona. (retrieved from http://www.hbw.com/node/932143 on 30 August 2016). 